\title{
Public Health Interventions toStabilize theAsymmetrical Sex Ratio in India
}

\author{
Saurabh RamBihariLal Shrivastava, Prateek Saurabh Shrivastava and Jegadeesh Ramasamy \\ Department of Community Medicine, Shri Sathya Sai Medical College \& Research Institute, Kancheepuram, India
}

*Corresponding author: Dr. Saurabh RamBihariLal Shrivastava, $3^{\text {rd }}$ floor, Department of Community Medicine, Shri Sathya Sai Medical College \& Research Institute, Ammapettai village, Thiruporur - Guduvancherry Main Road, Sembakkam Post, Kancheepuram - 603108, Tamil Nadu, India, Tel: +919884227224; E-mail: drshrishri2008@gmail.com

Received date: November 24, 2014, Accepted date: November 26, 2014, Published date: December 2, 2014

Copyright: (c) 2014 Shrivastava S, et al. This is an open-access article distributed under the terms of the Creative Commons Attribution License, which permits unrestricted use, distribution, and reproduction in any medium, provided the original author and source are credited.

\section{Editorial}

Worldwide, the demographic indicators of any population have gained a lot of importance as it not only provides the desired information required for development of health policies, but even enables evaluation of the existing strategies and comparison of these indicators on a regional or global level[1]. Sex ratio (i.e. the total number of females per thousand males), plays a significant role not only in epidemiological studies, but also depicts the socioeconomic and cultural pattern prevalent in the society [2]. Estimates of the latest census in India suggest a negative trend in the child sex ratio (viz. 911 females per 1000 males in 2011 in contrast to 927 females per 1000 males in 2001), and it emphasizes that due attention should be given to halt this trend $[3,4]$.

Research work has revealed the development of various genetic models to explore the dynamics of sex ratio[5]. Although, sex composition of a region is influenced by the heterogeneity in the mortality pattern of the population, \& sex selective migration, nevertheless a wide gamut of determinants has been identified which contribute to the imbalance of the country's sex ratio[1]. This includes factors like socio-cultural or religious beliefs or political opinion in shaping the attitude towards women in India (viz. preference for a boy is so deep rooted that women also prefer to have sons as giving birth to a son gives them social status and acceptance within the husband's family; pregnant women are often pressured by their husbands and members of his family, sometimes including verbal and physical abuse, to undergo prenatal sex determination and to abort the fetus if it is a female)[6,7]; demand for smaller families[8]; parents cognition[9]; history of recurrent miscarriages[10]; maternal migration [11]; poor awareness among health workers about indications of prenatal diagnostic techniques [2]; ineffective utilization of mass media to spread awareness[1,2]; preference for assisted reproductive techniques [12]; abuse of prenatal diagnostic technique [2]; practice of female feticide[6]; illegal abortions by doctors/untrained persons[6]; unethical practices by doctors[2]; loopholes in existing laws[13]; and ineffectiveness of the regulatory bodies to punish the offenders[6]. The impact of this skewed sex ratio (male-biased population) has shown significant influence on the incidence of crime as well as on the success of marriage[14].

In accordance with the achievement of Millennium Development Goal - 3 to promote gender equality and simultaneously ensure empowerment of women, the need of the hour is to develop a coordinated response involving all the stakeholders - policy makers, law enforcers, medical fraternity, media, non-governmental agencies, and the community itself $[1,2]$. This indirectly will negate the impact of a skewed sex ratio in the country as a whole, and thus a comprehensive strategy should be formulated to address all potential risk factors[2]. It should essentially consist of measures to create awareness among people through the use of media \& behavior change communication strategies[1,2]; periodic sensitization sessions for the medical practitioners to curb the practice of sex identification, illegal abortion \& feticide [6]; orientation of medical students regarding precise indications of prenatal diagnostic techniques[2]; development of guidelines to allow rationale usage of radiological tools [6]; creating a team of qualified professionals to supervise the use of radiological technology [2,6]; and quick \& stern punishment of the guilty persons[6].

To conclude, it is high time that policy makers should realize the importance of sex ratio and thus give due attention to reverse the declining trend of the sex ratio so that further untoward consequences can be averted.

\section{References}

1. Park K (2009) Demography and family planning: Textbook of Preventive and Social Medicine. (20th edn), BanarsidasBhanot, Jabalpur, Madhya Pradesh, India.

2. Avachat S, Raut P, Zambare M, Gund D, Pundkar R (2013) Perspectives of medical interns regarding female feticide and declining sex ratio in India. N Am J Med Sci 5: 469-472.

3. Ministry of Home Affairs, India (2011) Census of India-2011.

4. Ministry of Home Affairs, India (2001) Census of India-2001.

5. Argasinski K (2013) The dynamics of sex ratio evolution: from the gene perspective to multilevel selection. PLoS One 8: e60405.

6. Ramaiyah GJ, Chandrasekarrayya T, Murthy PV (2011) Declining sex ratio in India: Trends, issues and concerns. Asia Pac J SocSci 3: 183-198.

7. Madan K, Breuning MH (2014) Impact of prenatal technologies on the sex ratio in India: an overview. Genet Med 16: 425-432.

8. Puri S, Adams V, Ivey S, Nachtigall RD (2011) "There is such a thing as too many daughters, but not too many sons": A qualitative study of son preference and fetal sex selection among Indian immigrants in the United States. SocSci Med 72: 1169-1176.

9. Dama MS (2013) Cognitive ability correlates positively with son birth and predicts cross-cultural variation of the offspring sex ratio. Naturwissenschaften 100: 559-569.

10. Li J, Liu L, Liu B, Saravelos S, Li T (2014) Recurrent miscarriage and birth sex ratio. Eur J ObstetGynecolReprodBiol 176: 55-59.

11. Basten S, Verropoulou G (2013) 'Maternity migration' and the increased sex ratio at birth in Hong Kong SAR. Popul Stud (Camb) 67: 323-334.

12. Maalouf WE, Mincheva MN, Campbell BK, Hardy IC (2014) Effects of assisted reproductive technologies on human sex ratio at birth. FertilSteril 101:1321-1325.

13. Jha $P$, Kumar $R$, Vasa $P$, Dhingra $N$, Thiruchelvam $D$, Moineddin $R$ (2006) Low female[corrected]-to-male [corrected] sex ratio of children born in India: national survey of 1.1 million households. Lancet 367: 211-218.

14. Chipman A, Morrison E (2013) The impact of sex ratio and economic status on local birth rates. BiolLett 9: 20130027. 